\title{
EXISTENCE OF SALAFIYYAH ISLAMIC BOARDING SCHOOL IN THE MIDDLE ERA OF INDUSTRIAL REVOLUTION 4.0
}

\author{
Samudra Eka Cipta \\ Universitas Pendidikan Indonesia \\ Samudra.eka@student.upi.edu
}

\begin{abstract}
This research is a study that examines how pesantren as an Islamic education institution in Indonesia is able to survive amid the current modernization of pesantren education that changes the education system from traditional to modern. In this study there are several formulations of the problem, namely: 1) how was the initial development of Al-Barokah pesantren education, 2) how was the strategy of using the applied learning methods and models, 3 ) how was the final evaluation process at the Al-Barokah Islamic boarding school?. This research uses the content study method or literature study using several written studies and the use of qualitative methods in writing this article.
\end{abstract}

Keywords: Al Barokah, Islamic Education, Boarding School, Salafiyah, Student

Received 15 December 2019 Accepted 23 May 2020

\section{INTRODUCTION}

Education is an effort to shape the personality of children and students. In Islam education becomes a condition of obligation that must be carried out because in reality education can shape both behavior and morals, of course, blessed by GOD. At least, there is an education system that is applied in Islam. First is the school-based Islamic education system. Islamic schools are the same as schools in general while still referring to the curriculum. It's just that what is distinguished between public schools and Islamic schools is located in the contents of the curriculum, especially material and lessons with additions such as moral education, jurisprudence education, hadith education, and memorizing surah juz the 30th which is mandatory for students as graduation requirements both in the field of study and the next stage. Second, Islamic boarding school-based education system. Often people mention that the pesantren education system is a very and very traditional education system. It was seen that Islamic boarding school education was strongly emphasized in the figure of Kiai and Habib who were also leaders or founders of Islamic boarding schools. Regarding the methods of education applied by pesantren in addition to education, fiqh education, hadith education, and memorizing surah in pesantren-based Islamic education also always emphasizes quran interpretation education, and quran studies. This method is often referred to as the yellow book learning method. Islamic boarding schools also carry out several roles, besides being Islamic education institutions.

Regarding the education system applied in the Salafiyyah Islamic boarding school, it is very different from other formal education systems. Islamic boarding schools are mainly based on salafiyyah or the education system in traditional boarding schools is focused on teaching religious learning in general such as Fiqh, Arabic, Hadiths, Sufism, Tawhid, and Tafsir Qur'an. The learning methods applied by Bandungan, Sorogan and Wetonan at the Salafiyah Islamic boarding school. The Yellow Book learning is used as the main learning media in the Salafiyyah Islamic boarding school. The study of the Yellow Book is to study the legal provisions of Fiqh 
and Islamic Law. The use of instructional media in salafiyah Islamic boarding schools is also as simple as the use of chalk boards and chalk as the main learning media with the unsupported use of modern learning media such as LCD projectors, laboratories, and the use of internet networks as learning support media. According to Dhofier (2011, p. 76) (in Jawawi, S. 2011. p. 2) classifying boarding schools is divided into several groups of boarding schools including;

"The old type (classical), the learning is only focused on the Yellow Book which consists only of nahwu and sharaf. The new type of learning is teaching material outside of the subject matter of religious learning. In the new type of learning classes have begun to open classes such as elementary, junior high and high school like boarding schools such as schools".

In the Salafiyyah Islamic Boarding School, the kiai becomes a respected and respected figure of the santri. The charismatic figure of the kiai makes the santri to submit to and obey the kiai so that not a few santri violate orders or oppose the kiai. For santri, in addition to the kiai being a teacher, a kiai is likened to a waliyullah who will demand for his followers and followers. That is in the structural position of the Islamic boarding school, the position of the kiai is a leader and caretaker of the boarding school education system.

In the early 1980s there were changes and developments in pesantren educational institutions. Many Islamic boarding schools later transformed and adopted the modern education system as implemented by madrassas or formal schools. This is in line with the number of Islamic boarding schools that have begun to open classes such as MI, MA, MTS, SITP/public high school, religious tertiary institutions and even non-religious tertiary institutions. These changes can lead to new educational curricula in Islamic boarding schools with the existence of new educational patterns to the implementation of curriculum management in Islamic boarding schools. Supported by the role of the government in dealing with curriculum issues so that it results in changes in Islamic education as a whole, causing many Islamic boarding schools to change towards the modern (khalafiyah) of the traditional education system (salafiyah).

According to Nafi et al. [2] said that pesantren have a role as a religious, scientific, coaching, community development, and at the same time a cultural knot. The role is usually not formed directly through through step by step. The success of santri in understanding both Islam and teachings relating to Budi Perkerti was also seen as the success of a Kiai in delivering material to his students. The learning process that is applied generally starts with the delivery of the original subject matter, often the lecture method is carried out by the scholars and teachers and dignitaries starting to implement an independent learning system with the creation of study groups, then presenting. Al Barokah Islamic Boarding School is a boarding school that uses the Salafiyah method approach. Founded by KH. Mumuh Abdul Muhyi requested permission from the tower owner in 1982 when the land from the Al Barokah boarding school was one land with the tower owner on one of the cellular operators. The santri consisted of various regions such as Brebes, Cianjur, Sukabumi, Garut, and parts of Central and East Java. However, the reality of the Al Barokah Islamic Boarding School is that students who study at the lodge are almost all students.

\section{RESEARCH METHOD(S)}

Type of the Research

The method used by the author is a content study method that is using a literature study approach from several sources by examining a number of findings in the form of collecting books as a reference source as well as comparing the sources in this discussion. The author also conducted interviews in an effort to strengthen the data during the research process.

Place and Time of Research

Place the Research 
The research entitled "Student Education System in Al Barokah Islamic Boarding School" was held at the Al Barokah Islamic Boarding School located on Jalan Cilandak RT04/RW05, Sukasari District, Sukarasa Sub-District, Bandung, West Java.

Time of Research

The research was conducted on September January 2019, at 10.00 WIB - 14.00 WIB, but before the research was conducted the researchers visited the Al Barokah Islamic Boarding School in the framework of the pre-study on 12 February 2019.

\section{Research Subjects}

The subjects in this study were two head of Islamic boarding school and three students in Al-Barokah Islamic Boarding School. The total number of subjects interviewed totaled 5 people.

\section{Data Collections Technique}

To obtain the data needed in this study, the researcher collected data. The data collection techniques carried out include:

1. Observation

Observations carried out in this study were researchers who participated in teaching and learning activities but were not directly involved or only limited to observing. The observation activities in this study aimed to find out the implementation of learning in $\mathrm{Al}$ Barokah Islamic Boarding School.

2. Interview

In the interview activity the researcher used several research instruments in the form of a list of questions asked to the resource persons who had been prepared previously. The list of questions asked is then recorded using a voice note to record answers delivered by the interviewees.

\section{FINDINGS AND DISCUSSION}

The increasing number of santri who want to study in the pesantren. The status of the students who study at the Al Barokah Islamic Boarding School varies, mainly from students and students. Both MA / SMA, SMP / MTs students, also in Higher Education. In 2005, one of the tower operator owners asked KH. Mumuh Abdul Muhyi (Kang Sepuh), in the Sundanese tradition the mention of Kang Sepuh is the senior leader or the establishment of pondok pesantren. Then given the permission to build the tower, the owner of the tower always sent the infaq as well as being the main donor for the smooth running of the Al Barokah Islamic Boarding School. Since 2016 the Al Barokah Islamic Boarding School has at least 100 santri consisting of various regions such as Garut, Cianjur, Sukabumi, Brebes, and so on. To be part of the santri of the Al Barokah Islamic Boarding School the santri were not charged at all during the study period, but the santri were only charged per-person electricity costs of Rp 35,000. This is due to the sincerity of the sincerity of the teacher and the Kiai in guiding the students. But all this was done without intending but Al Barokah Islamic Boarding School remained consistent in carrying out its duties and obligations in guiding children into the behavior of karimah and of course as a provision in continuing the Islamic mission when the students had become alumni and returned to their respective regions. 
Differences between Students Who Follow Outside Learning Activities with Student Who Only Follow Learning Activities in Al Barokah Islamic Boarding School

In general, students in the Al Barokah Islamic Boarding School are not distinguished from the santri in general. The term 'santri' comes from an Indian language meaning it means the teacher of the Koran. According to C. C Berg (in Amrozi. 2014. p. 2), that the term santri comes from the term shastri which in Indian means people who know the sacred books of Hinduism. The word santri comes from the root word shastra which means holy books, religious books or books about science. So the understanding of pesantren is etymologically the origin of the santri which means the place of the santri. It's just that students who take part in outside learning activities such as schools and universities are not required to take part that are implemented by Kiai in full. In other words, the Al Barokah Islamic Boarding School strongly emphasizes the principles of humanism applied to its santri. This is in line with the presentation of Kang Anom [10] namely, "... student students are only required to take part in the lessons done by Kiai at night only, and the students are allowed to take part in their college activities in the morning." Besides the principle of humanism that is applied, Al Barokah Islamic Boarding School also allows students to obtain knowledge in general without having to stick to religious teachings. This was done so that the santri had the provision of knowledge both for the sake of the hereafter and their worldly interests to make the santri as educated and willing to educate.

In the perspective of Islam seeking knowledge is something that must be sought for every Muslim as long as the knowledge is still oriented to Islamic values. Searching for knowledge is also the same as looking for Ridho Allah Subhanallah Wa Taala because the process of gaining knowledge is done in a serious manner. Then there is a term, 'Look for science to China', meaning that humans will in essence continue to seek knowledge as long as humans live in the world for the good of themselves and others, especially in the provision after humans die.

\section{Learning Materials at Al Barokah Islamic Boarding School}

As in general, Al Barokah Islamic Boarding School is one of the pesantren that adheres to the salafiyah style or Islamic boarding school which still maintains Islamic values according to the beginning of the development of Islam. As a salafiyah boarding school, Al Barokah Islamic Boarding School in learning only focuses on issues relating to religion. Especially those relating to fiqh, hadith, and also the history of the Prophet Muhammad Saallahu Alaihi Wa Salaam. Santri are also taught about Islamic values that hold on to the Book of Yellow. According to Riki as students studying at the Al Barokah Islamic Boarding School said.

"Which is a yellow book is a book that studies the teachings of Islam but is presented in the form of bare Arabic letters, not only books with yellow paper but books that teach about Islamic values. Even though the paper is white, but if you see the contents of Islamic values, it is still referred to as Kitab Kuning" [11].

Regarding the origin of the naming of the yellow book as revealed by Riki it is probable that the word yellow scripture refers to the cover or cover of the Qur'an which is golden yellow. The Yellow Book itself is the result of writing from the scholars who started from tens of years and even hundreds of years ago. So that Kitab Kuning is also the only archive that is well preserved and cared for by the salafiyah santri. The yellow book also has types including Safinah and Jurumiyah. The Safinah book is one type of yellow book which teaches about jurisprudence and the science that discusses Islamic law. In the book of Safinah there are also Islamic laws from various views of four high priests such as Hanafi, Maliki, Hambali, and Syafii. Judging from the manner of behavior applied by the santri of the Al Barokah Islamic boarding school, it refers more to the views of Imam Syafii, especially in the Tauhid doktrine problem. But there are also a number of things that refer to Imam Maliki such as the problem of procedures in the form of other deeds. Nevertheless the santri must also study the views of other priests in order to solve a solution to problems concerning Islam. 
The Jurumiyah book is one type of yellow book where the Jurumiyah book contains nahwu and shorof. Nahwu is the rules of Arabic to know the shape of the word and its conditions when it is still one word (Mufrod) or when it is composed (Murokkab). This includes the discussion of Shorof. Because the Science of Shorof is part of the Science of Nahwu, which is emphasized in the discussion of the word form and its state when mufrod. Shorof is often known as the grammer Arabic letter. To be able to know the Yellow Book, of course, you must be able to first understand about nahwu and its shorof. Because in Arabic when we misread the form of the message, the meaning of what is delivered in the Book of Yellow will be different. It takes at least 3-6 years to master the contents of the yellow book if you understand correctly nahwu and shorof as the main rules and guidelines in learning Arabic. The length of time in studying the contents of the yellow book depends on the personality of the santri both from the level of intelligence and the level of willingness to learn a santri in understanding the contents of the Yellow Book.

\section{Teaching Methods in Al Barokah Islamic Boarding School}

The teaching method in the pesantren is bandhongan (known in Javanese as wethonan) and sorogan. Bandhongan is done by reading Arabic texts (in other words the Yellow Books), then the Kiai or lecturer translates into local languages, and at the same time explains the meaning of the contents contained in the book. This method was carried out in order to fulfill the cognitive competencies of the santri and expand scientific references for them [2]. Indeed, in the bandhongan method, there was hardly any discussion between the Kiai and his santri. Especially in salafiyah pesantren like Al Barokah. For them this is a form of respect for the Kiai, also a tradition of one-way learning known as the chalk and talk method. The learning media used are very simple consisting of chalk and blackboard. The absence of LCD projectors or the like as supporting and supporting learning. The use of the one-way method (lecture) already existed at the beginning of the development of the history of Islamic Civilization. There is a reason why this method is still maintained in Islamic boarding schools, especially those with salafiyah models, does not mean that when students want to ask Kiai in the learning process, the Kiai cannot answer the questions raised by the students but it is a form of respect for the Kiai and leads to more forms of ethics santri to Kyai. For the students' views of the Al Barokah Islamic Boarding School, all the material presented by Kiai already has the truth that has been taken. So that the students also knew very well that the Kiai in terms of delivering the material were not from the origin but had read a number of references relating to religious issues, especially considering that the Kiai had once also been part of the santri. So it is not surprising that this bandhongan method was taught from generation to generation, even since the Kiai and administrators were still santri and received similar education by their teachers.

Not only is the bandhongan method used, as for the sorogan method. This method aims to make students demanded to be more active learning in understanding the books that have been taught before by Kiai. Kiai gave the santri a minute to discuss the intent or essence of the contents of the Yellow Book. After discussion then Kiai told the students to face him to convey what had been discussed. Then after delivering what the Kiai had discussed, strengthening the material that had been given before. Al Barokah Islamic Boarding School when viewed from its teaching staff only has three Kiai. As explained by Lilis, "the instructors of the Al Barokah Islamic boarding school consist of Kang Sepuh (KH. Mumuh Abdul Muhyi), Kang Anom (Haji Yayat Nurul Hidayat), and Kang Haji Usman" [12]. So the learning pattern is different from modern Islamic boarding schools (khalafiyah). The use of methods in modern boarding schools is almost the same as the use of various learning methods and approaches that exist in public schools.

Particularly for the Al Barokah Islamic Boarding School, the santri strongly instilled the values of character in the Kiai figure, and ethics were highly respected. Maintaining ethics as well as seeking blessings also looks for Ridhoan from Allah Subhanallah Wa Taala. If one of 
the student who does not maintain ethics with the Kiai, the knowledge gained during his time as a santri will not be blessed even if he is an alumni. So respect for the Kiai that when he met the Kiai the santri bowed his body as a form of respect to the Kiai.

\section{Learning Evaluation Applied}

The application of the curriculum applied refers to the Learning of the Yellow Book as teaching material in the Al-Barokah Islamic boarding school. On the other hand local materials or traditions from the Al-Barokah Islamic Boarding School are still maintained, one of them with a one-way learning system.

Al Barokah Islamic Boarding School has a unique form of evaluation, namely the santri test in front of the Kiai individually and there are times in groups. The indicator of the Test is how to read the yellow book and the Qur'an properly, the test method is known as imtihan. The schedule of the test was carried out when there were certain celebrations, especially during the Birthday of the Prophet Saallahu Alaihi Wa Salaam. The test was conducted to determine the extent of understanding of the students in understanding the contents of the Book of Yellow. Another form of test is tablighan, in this test the student saw to be required to become preachers in conveying a problem related to Islam. The indicator of the tablighan test is that students are required to know the arguments of the Qur'an and Al Hadith arguments when they will explain their lectures before the Kiai. In addition, students were also required to find and find out the substantive solutions of the lectures delivered.

The results of the two tests, both imitations and tablighan, were not in numbers or quantitative, such as report cards, but the results of the tests came from the blessing of the Kiai who judged them. A student named Hanan said, "There is no report card as a result of the evaluation of learning but rather the appreciation made by the Kiai towards the students." (Interview with Hanan September 13, 2018). This is because the Al Barokah Islamic Boarding School does not have a class system and only studies in a hall. Nor does it have a class level so it forms a hierarchical, Kiai's blessing is the main reference for the santri.

\section{Tradition maintained at Al Barokah Islamic Boarding School}

Tradition is a manifestation of the cultural results of society that are continuously inherited or carried out continuously. In the Al Barokah Islamic Boarding School the traditions that continue to be carried out by the Kiai and boarding school officials include:

1. Barzanzi, a tradition that explains the history of the life of Rasulallah Saallahu Alaihi Wa Salaam. The difference between Barzanzi and Nabawiyah Sirah lies in bookkeeping. Barzanzi is usually delivered directly by Kiai but the implications are more on prayer. So in essence, Barzanzi is a combination of the history of the prophet who was sung through prayer.

2. Marhaba, is a tradition in Sufism, namely the process towards the level of worship or interaction between humans and Allah Subhanallah Wa Taala to reach ma'rifatullah or human beings have reached the culmination of worship between man and His God. The practice of marhaba is prayer to Allah Subhanallah Wa Taala and Prophet Muhammad Saallahu Alaihi Wa Salaam.

3. Muludan, is a tradition in commemoration of the birthday of Prophet Muhammad Saallahu Alaihi Wa Salaam. In addition, this tradition also commemorates the services that have been given to Al Barokah Islamic Boarding School. The form of this tradition is the study of both the santri and the surrounding community regarding the history and struggle of the Prophet Muhammad Sallahu Alaihi Wa Salaam in spreading the cause of Islam.

4. Habkah, is a tradition that aims to strengthen the relationship between alumni, santri, and Kiai Al Barokah Islamic Boarding School. Habkah itself is (Himpunan Alumni Al Barokah). The program is held once every year. Regarding the study period at the Al Barokah Islamic boarding school it is not determined to be a maximum of several years, 
but depends on the maturity level of the santri in plunging into the community and determined by Kiai's blessing that he is to become an alumni or still studying at the Islamic boarding school (pesantren).

\section{CONCLUSION}

In the early 1980s there were changes and developments in pesantren educational institutions. Many Islamic boarding schools later transformed and adopted the modern education system as implemented by madrassas or formal schools. As a traditional education the Al-Barokah Islamic boarding school still maintains traditional teaching and learning traditions. This boarding school prioritizes the use of the yellow book as the main medium of learning. Al-Barokah Islamic boarding school only relies on the blessing of the kiai as an evaluation process in learning at Al-Barokah Islamic boarding school. Al-Barokah Islamic Boarding School has a unique tradition that has been maintained since this educational institution was established. The curriculum created is a curriculum that is applied directly by the kiai as mentors in learning in traditional pesantren.

\section{REFERENCES}

[1] H.M. Baidlawi, Modernisasi pendidikan islam: telaah kurikulum pesantren mahasiswa, Tadris: Jurnal Pendidikan Islam 1 (2006) 154-167.

[2] M.D. Nafi et al., Praksis Pembelajaran Pesantren, LKIS Pelangi Aksara, Yogyakarta, 2007.

[3] E. Fatmawati, Manajemen pengembangan kurikulum pesantren mahasiswa. disertasi. Universitas islam negeri maulana malik ibrahim, malang, 2015.

[4] H. Herdiansyah, Metodologi Penelitian Kualitatif untuk Ilmu-Ilmu Sosial, Salemba Humanika, Jakarta, 2011.

[5] I. Hielmy. Pesan Moral dan Pesantren: Meningkatkan Kualitas Umat, Menjaga Ukhuwah. Nuansa, Bandung, 1999.

[6] Mastuhu, Dinamika Sistem Pendidikan Pesantren: Suatu Kajian Tentang Unsur dan Nilai Sistem Pendidikan Pesantren, INIS, Jakarta, 1994.

[7] A. Saifuddin, Eksistensi Kurikulum Pesantren Dan Kebijakan Pendidikan, Eksistensi Kurikulum Pesantren Dan Kebijakan Pendidikan. JPAI 3 (2015) 207-234.

[8] Sugiyono, Metode Penelitian Kuantitatif, Kualitatif dan R\&D, Alfabeta, Bandung, 2009.

[9] Sukamto, Kepemimpinan Kiai Dalam Pesantren, LP3ES, Jakarta, 1999.

[10] Interview with Yayat Nurul Hidayat, 13 September 2018

[11] Interview with Riki, 13 September 2018.

[12] Interview with Lilis Siti Nurjannah, 13 September 2018. 